\title{
Educational Process Digitalization: Introduction of Cloud Laboratory Complexes
}

\author{
Alexey V. Bataev \\ Graduate school of public and financial management \\ Peter the Great St.Petersburg Polytechnic University \\ St. Petersburg, Russia \\ bat_a68@mail.ru
}

\author{
Ksenia I. Bataeva \\ Orient Express Bank \\ St. Petersburg, Russia \\ Ksenia_88_08@bk.ru
}

\begin{abstract}
Today's world is a dynamic system in which development is determined by the large-scale implementation of information and communication technologies permeating all spheres of economic development. The introduction of digital technologies has led to the formation of a new direction in the economy - the digital economy, the drivers of which is Industry 4.0 and Fintech. Today, the most innovative technologies in the development of the digital economy are big data, cloud computing, artificial intelligence, cyber-physical systems that determine the main directions of modern development. Digital transformation of economic development not only requires new specialists who are able to develop and introduce innovative technologies, but also dictates the need for new approaches in the educational process itself. The transformation of the education sector through the introduction of new digital technologies, in particular, cloud computing is analyzed in the paper. Cloud computing technologies are widely used in all areas of development, in connection with this, a study of the global cloud computing market is conducted, and its key parameters are analyzed: financial volumes, growth rates, development prospects. Particular attention is paid to areas of using cloud technologies in the educational sphere, priority areas were identified, and their further implementation was assessed. One of the main opportunities for the use of cloud technologies in the educational process is the introduction and use of modern training laboratories of various orientation using cloud computing. The cloud automated banking system BISquit was introduced at the St. Petersburg Polytechnic University of Peter the Great on the basis of the "Computer Technologies in Banking" laboratory. This system allows getting practical knowledge about financial institutions' operation within the walls of an educational institution. The creation and implementation of such type of laboratory in the educational process is discussed in the article.
\end{abstract}

Keywords - information technology management; educational process; cloud computing; educational laboratories; automated banking system

\section{INTRODUCTION}

Today's world is at the threshold of the fourth industrial revolution, which involves the large-scale implementation of the most innovative information and communication technologies in all areas: industry, services, infrastructure, that is, everything that surrounds a person in his or her daily life. The formation of a new technological order implies the creation of "smart production", "smart cities", "smart medicine" and other areas in all spheres of development, but a distinctive feature of this digital transformation of our life is the synthesis of these areas into a single information field, allowing to solve problems in any direction due to a comprehensive analysis of the problem from all points of view for each individual. [1-4]

Such large-scale transformations require corresponding changes in the educational process, which should provide training of the highest-level specialists for solving relevant problems that are already emerging now for further digital development.

On the one hand, the digitalization of the world economic system requires the training of specialists in completely new areas, and on the other hand, it provides for new innovative approaches in the field of education itself. One of such approaches is the introduction of cloud computing technologies, allowing to provide a new quality level of education due to the scaling of educational processes, providing access to truly unlimited resources, in the form of modeling any business processes on computer capacities.

One of these opportunities is the creation of educational laboratories that use all the advantages of cloud technologies to organize the educational process, providing innovative approaches in the field of education.

\section{KEY RESEARCH FINDINGS}

\section{A. Definition and classification of cloud computing technology}

The concept of cloud computing originated in the 1960s, when John McCarthy, one of the specialists in the field of information technology, suggested that someday computer computing would be provided remotely using publicly available applications.

Cloud computing is a technology that involves the formation of software applications (computing clouds) that allow the user to access them through computer networks.

Today, there are three main types of cloud computing:

- Infrastructure as a service (IaaS) assumes computer capacity for the deployment of its software applications as remote access; 
- Software as a service (SaaS) involves the provision of software for use in their own purposes;

- $\quad$ Platform as a service (PaaS) implies the provision of a cloud infrastructure to a user for the deployment of their own or acquired applications that allow solving the tasks required with their help, in this case the user has access to some infrastructure configuration parameters;

- Business process as a service (BPaaS) involves the provision of a remote form of business process, allowing solving the problems facing the company;

- Security management as a service (SMaaS) requires that due to the cloud the user can solve a range of issues related to security.

Depending on the form of providing cloud computing, there are three types of clouds:

- $\quad$ Private clouds. This is a type of clouds, which involves the formation of a computing cloud within its organization and provides access within it, in which case the cloud is managed by the company itself;

- Public clouds. This is a type of clouds, which involves the creation of cloud capacity by a third-party organization and providing them to various companies as a third-party service. In this case, cloud management is available only to the organization that created it;

- Hybrid clouds are clouds that combine private and public cloud technologies. [2], [4], [5-7]

\section{B. Evaluation of the global cloud computing market}

Cloud computing is one of the drivers for the digitalization of the entire economy. By 2025, the cloud computing market is expected to reach $\$ 603.2$ billion (Fig. 1). [3], [6], [8]

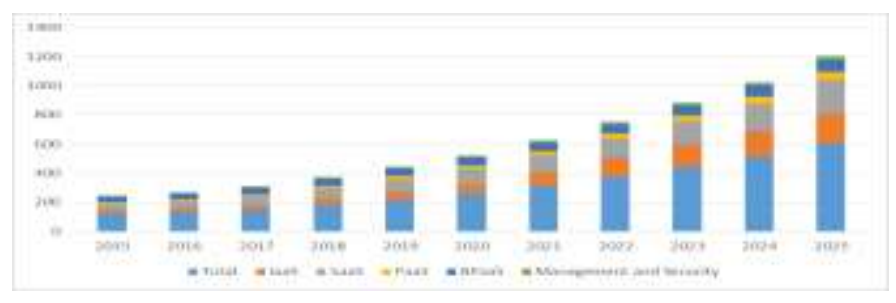

Fig. 1. The dynamics of the development of cloud computing, billions of dollars

As can be seen from the diagram the SaaS segment is in the first place, which is supposed to reach $\$ 229.7$ billion by 2025 . The average annual market growth rate is over $17.4 \%$, which is 2.9 times higher than the total IT technology market.

Today, cloud technologies have found their application in almost all fields. However, the leading position was occupied by the healthcare sector in 2018, which accounted for $\$ 12.1$ billion (Fig. 2). [1], [9]

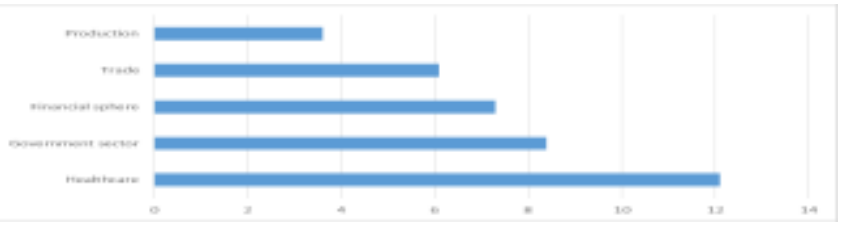

Fig. 2. The leading sectors on introduction of cloud computing, billions of dollars

The leader in introducing cloud computing is the United States whose volume is about $75 \%$ of the total market (Fig. 3). $[5,6],[10]$

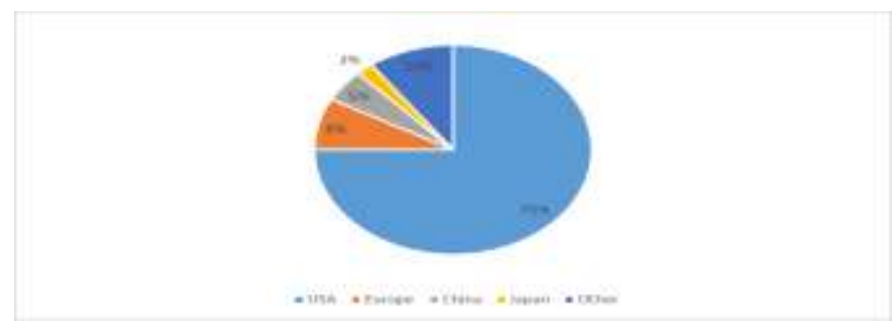

Fig. 3. Countries - leaders in implementing cloud computing, percent

Russia occupies a share of $0.3 \%$ on the global market and its figure will rise to $0.35 \%$ by 2020 .

\section{Evaluation of the use of cloud computing in education}

Despite the large-scale introduction of cloud computing, the market for these technologies in education has not reached such impressive results as in other areas. Only in 2025, its volume can reach the figure of $\$ 1.1$ billion (Fig. 4). [11-13]

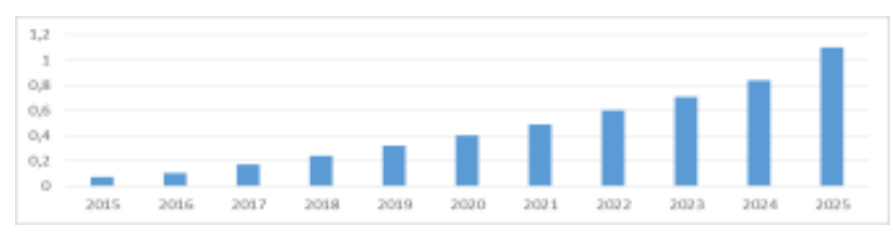

Fig. 4. Dynamics of the volume of the global market for cloud computing in education, billions of dollars

Using cloud computing technologies in education can be based on the benefits they provide:

- cloud computing can significantly save on the purchase, use, upgrade of software and hardware;

- $\quad$ security, resiliency and scalability of any processes using cloud computing;

- $\quad$ remote access from anywhere with Internet access.

The largest volume of using cloud computing in education belongs to ensuring access to computer programs that makes about 30\% (Fig. 5). [7], [14, 15] 


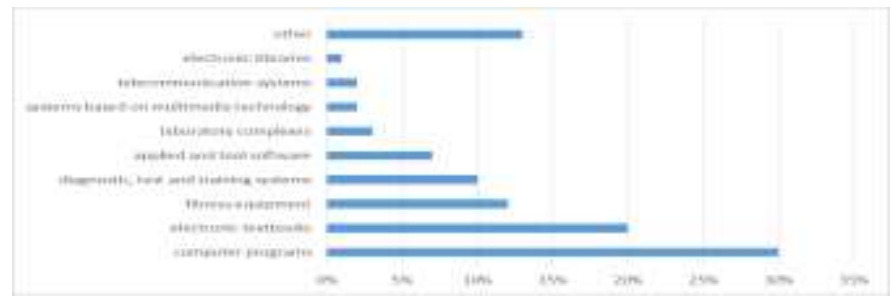

Fig. 5. Using cloud computing in education, percent

\section{Perspectives for the introduction of cloud laboratory} complexes by the example of an automated banking system

Laboratory complexes is one of the areas of using cloud computing in the field of education, which are not widely used today. However, their use is quite promising.

For example, in St. Petersburg Polytechnic University of Peter the Great, the laboratory "Computer Technologies in Banking" was created in 2005, which was based on studying the work of a financial institution based on the automated banking system "BISquit". The structure of the laboratory is shown in Fig. 6.

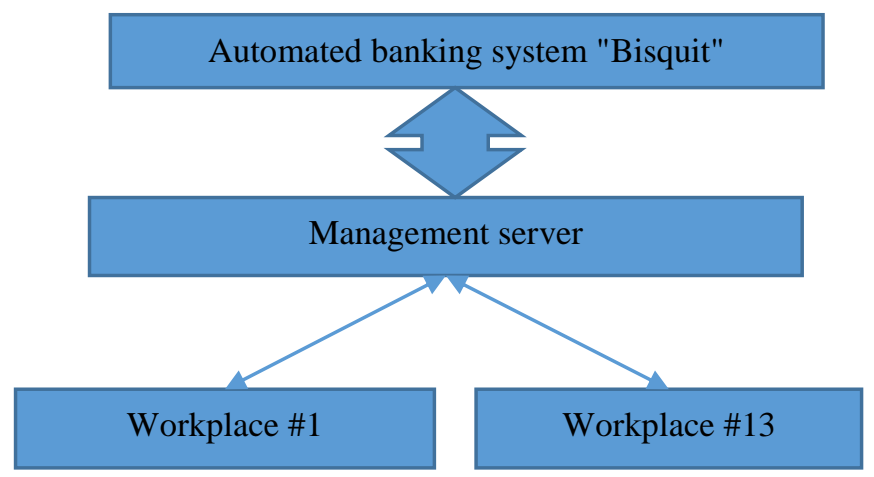

Fig. 6. The structure of the educational laboratory "Computer technologies in banking"

The laboratory consisted of 15 computers, one of which was running the Linux operating system, and that was where the automated banking system was located. The second computer had the network operating system Windows NT, whose task was to manage a computer network of thirteen workplaces, on which there was a simple Windows operating system. Workplaces were personal computers whose task was to provide user access to the banking system.

The bandwidth of the school laboratories was not very high due to limited workplaces, in connection with which it conducted practical training in two disciplines: Banking Information Technologies and Banking. The volume of performed practical exercises is presented in Table 1 with the full workload of the laboratory.

TABLE I. CRYPTOCURRENCY DEVELOPMENT STAGES

\begin{tabular}{|l|c|l|}
\hline Discipline & $\begin{array}{c}\text { Time for practical } \\
\text { training from total } \\
\text { amount, \% }\end{array}$ & \multicolumn{2}{|c|}{ Result } \\
\hline $\begin{array}{l}\text { Banking } \\
\text { Information }\end{array}$ & 50 & $\begin{array}{l}\text { Gaining practical skills in the } \\
\text { automated banking system, }\end{array}$ \\
\hline
\end{tabular}

\begin{tabular}{|l|c|l|}
\hline Discipline & $\begin{array}{c}\text { Time for practical } \\
\text { training from total } \\
\text { amount, \% }\end{array}$ & \multicolumn{1}{|c|}{ Result } \\
\hline Technologies & & $\begin{array}{l}\text { introduction to the work of junior } \\
\text { and middle management of the } \\
\text { bank }\end{array}$ \\
\hline Banking & 25 & $\begin{array}{l}\text { Gaining practical skills in } \\
\text { studying the operations of a } \\
\text { financial institution; making } \\
\text { economic calculations on the } \\
\text { main operations of a credit } \\
\text { institution }\end{array}$ \\
\hline
\end{tabular}

The restriction on the implementation of practical work turned out due to a small number of workplaces and a large number of students in groups. In this regard, they had to be divided into separate subgroups.

Accordingly, the laboratory was modernized in 2016: the automated banking system was transferred to a virtual machine. Virtualization is one of the foundations of cloud computing, which consists in creating an application model that offers some advantages over the original configuration, in particular, removing the restriction that exists in its original form.

As a result, the structure of the laboratory took the following form (Fig. 7).

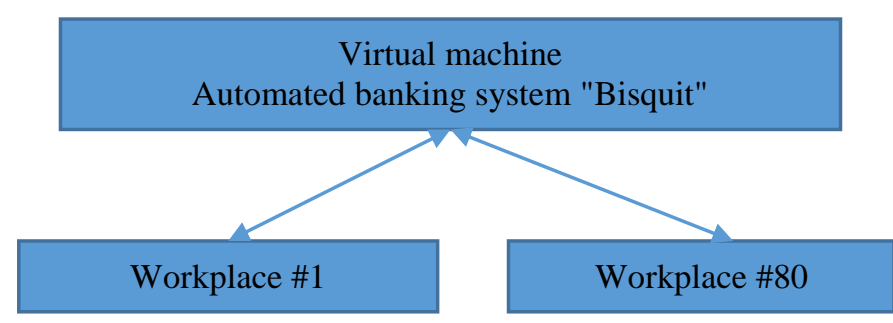

Fig. 7. The structure of the educational laboratory after modernization

As a result of the transformation of the laboratory, a private cloud was formed, allowing access to several computer classes at once. This increased the number of workplaces to eighty and greatly expanded the capabilities of the laboratory. It should be noted that the number of workplaces is limited in this case by the number of computers in laboratories connected to the computer network, and not by the capabilities of the virtual machine.

Because of increased traffic, the provision of the educational laboratory for other disciplines has increased (Table 2).

TABLE II. TIME OF PRACTICAL TRAINING FOR ACADEMIC DISCIPLINES AFTER THE MODERNIZATION OF THE EDUCATIONAL LABORATORY

\begin{tabular}{|l|l|l|}
\hline \multicolumn{1}{|c|}{ Discipline } & $\begin{array}{l}\text { Time for practical } \\
\text { training from } \\
\text { total amount, \% }\end{array}$ & \multicolumn{1}{|c|}{ Result } \\
\hline $\begin{array}{l}\text { Money, } \\
\text { credit, banks }\end{array}$ & 50 & $\begin{array}{l}\text { Studying the structure of a } \\
\text { financial institution, its goals and } \\
\text { objectives }\end{array}$ \\
\hline $\begin{array}{l}\text { Audit of } \\
\text { banks }\end{array}$ & 100 & $\begin{array}{l}\text { Considering the issues related to } \\
\text { audit of banks, introduction to the } \\
\text { credit and deposit policies }\end{array}$ \\
\hline $\begin{array}{l}\text { Banking } \\
\text { information }\end{array}$ & 100 & $\begin{array}{l}\text { Gaining practical skills in the } \\
\text { automated banking system, }\end{array}$ \\
\hline
\end{tabular}




\begin{tabular}{|l|l|l|}
\hline \multicolumn{1}{|c|}{ Discipline } & $\begin{array}{l}\text { Time for practical } \\
\text { training from } \\
\text { total amount, \% }\end{array}$ & \multicolumn{1}{|c|}{ Result } \\
\hline technologies & & $\begin{array}{l}\text { introduction to the work of junior } \\
\text { and middle management of the } \\
\text { bank }\end{array}$ \\
\hline Banking & 100 & $\begin{array}{l}\text { Gaining practical skills in } \\
\text { studying the operation of a } \\
\text { financial institution; making } \\
\text { economic calculations on the main } \\
\text { operations of a credit institution }\end{array}$ \\
\hline $\begin{array}{l}\text { Bank } \\
\text { accounting }\end{array}$ & 100 & $\begin{array}{l}\text { Studying of bases of accounting at } \\
\text { financial institutions by concrete } \\
\text { examples in the automated } \\
\text { banking system }\end{array}$ \\
\hline $\begin{array}{l}\text { International } \\
\text { Financial } \\
\text { Reporting } \\
\text { Standards }\end{array}$ & 50 & $\begin{array}{l}\text { Studying of the basic reporting } \\
\text { and document flow at financial } \\
\text { institution }\end{array}$ \\
\hline
\end{tabular}

At the same time, the incomplete load on some disciplines is explained not by the shortage of workplaces, but studying of other questions within a course which are not connected with financial institutions.

In the future, there is a task to expand capabilities of the educational laboratory in the direction of access to the automated banking system not only on internal network, but also to provide full access on the Internet and to unite this laboratory with the electronic courses conducted on the Moodle platform. This can ensure full access to all opportunities of the formed system for all forms of education full-time, part-time, and to a greater extent correspondence

\section{CONCLUSIONS}

Modern development is accompanied by the mass introduction of digital technologies in all areas. Therefore, an innovative direction has emerged within the traditional economy - a digital economy, based on the creation of new business models through the introduction of information and communication technologies.

The formation of an innovative approach to the development of the economy requires the training of specialists who are able to provide new challenges in the modern world, and it allows to provide innovative approaches in the educational process through the introduction of digital technologies, one of which is cloud computing.

Cloud computing is one of the drivers in digital technologies. Its volume of the global market is expected to exceed 680.3 billion dollars by 2025, and it may exceed the market of IT technologies by 2.9 times by the average annual growth rate.

Healthcare is the market leader in cloud computing. In 2018 , the volume of implementations was about $\$ 12.1$ billion. The volume of the cloud computing market in education is supposed to reach $\$ 1.1$ billion only by 2025 .

One of the main directions in the field of education is access to computer programs, which is over $30 \%$, electronic textbooks are on the second place, whose figure is about $20 \%$, and third place is virtual simulators, with an indicator of $12 \%$.

The introduction and use of cloud laboratory complexes are one of the directions in the field of education, the prospects of which are quite well illustrated by the educational laboratory
"Computer Technologies in Banking", created at Peter the Great St. Petersburg Polytechnic University based on an automated banking system. Due to its modernization by virtualization banking applications and the formation of a private cloud, it was possible to expand the number of workplaces by 6.2 times. The configuration of the system itself was simplified, the number of disciplines and practical exercises that are based on the cloud laboratory complex were increased, and the amount of practical trainings grew by 6.6 times.

\section{REFERENCES}

[1] Khmelevsky Y., Voytenko V. Cloud computing infrastructure prototype for university education and research, Proceedings of the 15th Western Canadian Conference on Computing Education. ACM, 2010.

[2] Arpaci I. Antecedents and consequences of cloud computing adoption in education to achieve knowledge management. Computers in Human Behavior, Vol. 70, 2017, pp. 382-390.

[3] Rahi S.B., Bisui S., Misra S.C., Identifying the moderating effect of trust on the adoption of cloud based services, International Journal of Communication Systems, Vol. 30, issue. 11, 2017, pp.1-19, (Impact factor: 1.717), https://doi.org/10.1002/dac.325

[4] Rahi S.B., Bisui S., Misra S.C., "Identifying critical challenges in the adoption of cloud based services", International Journal of Communication Systems, Vol. 30, issue 12, 2017, pp. 1-14, (Impact factor: 1.717), https://doi.org/10.1002/dac.3261

[5] Misra S. C., Rahi S.B, Bisui S., Singh A., Factors Influencing the Success of Cloud Adoption in the Semiconductor Industry, Software Quality Professional Magazine, Vol. 21, issue 2, 2019

[6] Erdil D. C. et al. Toward Developing a Cloud Computing Model Curriculum //Proceedings of the 2019 ACM Conference on Innovation and Technology in Computer Science Education. ACM, 2019, pp. 255256.

[7] Hasanein H.A.A., Naser S.S.A. An intelligent tutoring system for cloud computing, 2017.

[8] Attaran M., Attaran S., Celik B.G. Promises and challenges of cloud computing in higher education: a practical guide for implementation //Journal of Higher Education Theory and Practice, Vol. 17, №. 6, 2017.

[9] Karim F., Rampersad G. Cloud Computing in Education in Developing Countries. Computer and Information Science, Vol. 10, №. 2, 2017, p. 87-96.

[10] Al-Shqeerat H. A. K. et al. Cloud computing security challenges in higher educational institutions-A survey //International Journal of Computer Applications, Vol. 161, №. 6, 2017, pp. 22-29.

[11] Necheukhina N.S., Matveeva V.S., Babkin I.A., Makarova E.N. Modern approaches to the educational process aimed at improving the quality of highly qualified personnel training Proceedings of 2017 IEEE 6th Forum Strategic Partnership of Universities and Enterprises of Hi-Tech Branches (Science. Education. Innovations), SPUE, 2017, pp. 192-195.

[12] Burdakova G., Byankin A., Usanov I., Pankova L. Smart technologies in education and formation of entrepreneurial competencies IOP Conference Series: Materials Science and Engineering, 2019, Vol. 497.

[13] Kozlov O.A., Rodionov D.G., Guzikova L.A. Information security problems in educational institutions in conditions of network interaction International Conference on Information Networking, 2018, pp. 267269.

[14] Razinkina E., Pankova, L., Trostinskaya I., Pozdeeva E., Evseeva L., Tanova A. Student satisfaction as an element of education quality monitoring in innovative higher education institution E3S Web of Conferences, 2018, Vol. 33.

[15] Kalmykova S.V., Pustylnik P.N., Razinkina E.M. Role scientometric researches' results in management of forming the educational trajectories in the electronic educational environment Advances in Intelligent Systems and Computing, Vol. 545, 2017, pp. 427-432. 